\title{
Hemşirelik öğrencilerinin stresle başetme durumları ve madde kullanım öykülerinin belirlenmesi
}

\author{
Identifying nursing students' methods to deal with stress and their substance use \\ histories
}

Gülay Taşdemir Yiğitoğlu, Türkan Turan, Gülbahar Korkmaz Aslan, Asiye Kartal

Gönderilme tarihi:03.12.2018

Kabul tarihi:10.07.2019

\begin{abstract}
Özet
Amaç: Bu çalışmanın amacı hemşirelik öğrencilerinin stresle başetme durumları ve madde kullanım öykülerinin belirlenmesidir.

Gereç ve yöntem: Tanımlayıcı olan bu araştırmanın evreni ve örneklemini bir sağıık bilimleri fakültesi hemşirelik bölümünde öğrenim gören araştırmaya katılmak isteyen 371 hemşirelik öğrencisi oluşturmuştur. Veriler araştırmacılar tarafından hazırlanan anket formu, Stresle Başetme Tarzları Ölçeği ile toplanmıştır. Analiz için SPSS 18.0 istatistik programıyla Sayı, Yüzdelik, Student t Testi, Tek Yönlü Varyans analizi kullanılmıştır.

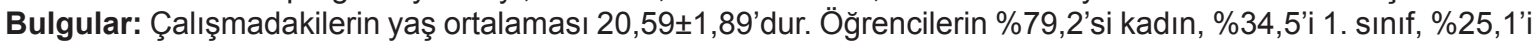
2. sınıf, $\% 16,4$ 'ü 3. sınıf, \%24,0'ü 4. sınıftır. Katılımcıların büyük çoğunluğu aile ile $(\% 82,7)$ ve çevre ile olan iletişimini (\%83) iyi olarak belirtmişlerdir. Çalışmaya alınanların \%42,3'ü okul ortamındaki stresin sınavlar, dersler ve ders işleme şeklinden kaynaklandığını bildirmişlerdir. Öğrencilerin çok büyük bir çoğunluğunun $(\% 99,5)$ sigara ve alkol dışında herhangi bir bağımlılık yapıcı madde kullanmadıkları, \%81,7'sinin şu anda sigara ve \%83,0'ünün alkol kullanmadıkları belirlenmiştir. Öğrencilerin stresle baş etme tarzları ölçeği alt boyut puanları; kendine güvenli yaklaşım $12,61 \pm 4,01$, iyimser yaklaşım $8,38 \pm 2,87$, kendine güvensiz/çaresiz yaklaşım $11,95 \pm 4,55$, boyun eğici yaklaşım $6,68 \pm 3,42$ ve sosyal destek arama 7,02 $\pm 1,90$ 'dır.

Sonuç: Çalışmaya alınanların en fazla kendine güvenli yaklaşım, ardından kendine güvensiz/çaresiz yaklaşım ve en az olarak da boyun eğici yaklaşım alt boyutunu kullandıkları saptanmıştır. Bu sonuç öğrencilerin stresle başa çıkma konusunda etkili yöntemler kullandıklarını, stres yönetimi konusunda daha az sorun yaşadıklarını göstermektedir.
\end{abstract}

Anahtar Kelimeler: Hemşirelik öğrencileri, madde kullanımı, stresle başetme.

Taşdemir Yiğitoğlu G, Turan T, Korkmaz Aslan G, Kartal A. Hemşirelik öğrencilerinin stresle başetme durumları ve madde kullanım öykülerinin belirlenmesi. Pam Tıp Derg 2019;12:371-385.

\begin{abstract}
Purpose: The purpose of this study was to identify nursing students' methods to deal with stress and the history of their substance use.

Materials and methods: The population and sample of this descriptive study consisted of 371 nursing students who wanted to participate in the study in the nursing department of a faculty of health sciences. Data was collected with questionnaire form, Methods to Deal with Stress Scale. For analyses, Number, Percentage, Student t Test, One Way Variance analysis were used with SPSS 18.0 statistics program.

Results: Mean of ages of participants in the study was found as $20.59 \pm 1.89 .79 .2 \%$ of students were female and $34.5 \%$ of them were 1 st grade, $25.1 \%$ were 2 nd grade, $16.4 \%$ were 3 rd grade and $24.0 \%$ were 4 th grade. Majority of participants $(82.7 \%)$ stated that in-family communication and their communication with environment $(83 \%)$ were fine. $42.3 \%$ of participants stated that stress in school environment was stemmed from exams, courses and lecturing methods. It was determined that majority of students (99.5\%) did not use any substance other than cigarette and alcohol, and $81.7 \%$ of them did not currently use cigarette and $83.0 \%$ of them did not currently use alcohol. Subscale score means of students' methods to deal with stress scale were found as follows; self-confidence approach was $12.61 \pm 4.01$, optimistic approach was $8.38 \pm 2.87$ unconfident/desperate approach was $11.95 \pm 4.55$, submissive approach $6.68 \pm 3.42$ and social support search was $7.02 \pm 1.90$.

Conclusion: The participants were found to use the most self-confidence approach, followed by an unconfident/ desperate approach and at least the submissive approach sub-scales. This result shows that the students use effective methods for coping with stress and have less problems in stress management.
\end{abstract}

Gülay Taşdemir Yiğitoğlu, Dr. Öğr. Üyesi, Pamukkale Üniversitesi Sağlık Bilimleri Fakültesi Hemşirelik Bölümü Psikiyatri Hemşireliği Anabilim Dalı, DENiZLi, e-posta: gyigitoglu@pau.edu.tr, (orcid.org/0000-0002-8075-7155) (Sorumlu yazar)

Türkan Turan, Doç. Dr. Pamukkale Üniversitesi Sağlık Bilimleri Fakültesi Hemşirelik Bölümü Çocuk Sağlığı ve Hastalıkları Hemşireliği Anabilim Dalı, DENiZLİ, e-posta: turkanturan@pau.edu.tr (orcid.org/0000-0002-8427-672X)

Gülbahar Korkmaz Aslan, Dr. Öğr. Üyesi, Pamukkale Üniversitesi Sağlık Bilimleri Fakültesi Hemşirelik Bölümü Halk Sağlığı Hemşireliği Anabilim Dalı, DENIZLI, e-posta: gulbahark@pau.edu.tr (orcid.org/0000-0003-0763-3671)

Asiye Kartal, Doç. Dr. Pamukkale Üniversitesi Sağlık Bilimleri Fakültesi Hemşirelik Bölümü Halk Sağlığı Hemşireliği Anabilim Dalı, DENizLí, e-posta: akartal@pau.edu.tr (orcid.org/0000-0001-7475-0013) 
Key Words: Nursing students, degenerative arthritis, arthroplasty.

Taşdemir Yiğitoğlu G, Turan T, Korkmaz Aslan G, Kartal A. Identifying nursing students' methods to deal with stress and their substance use histories. Pam Med J 2019;12:371-385.

\section{Giriş}

Madde bağımlılığı günümüzde yaygınlığının giderek artması nedeniyle pek çok tıbbi, sosyal, ekonomik ve yasal sorunlara neden olan önemli bir sağlık ve sosyal sorun halini almıştır [1].

Bağımlıık, bireyin beden ve ruh sağlığını, aile, toplum ve iş uyumunu bozacak derecede sık ve fazla miktarda madde kullanma, madde alma isteğini durduramama olarak tanımlanmaktadır [2]. Birleşmiş Milletler Uluslararası Uyuşturucu Kontrol Programı'nın tahminlerine göre dünya genelinde madde kullanımı giderek artmaktadır. Tahminen 29 milyon insanın madde bağımlısı olduğu, 15-64 yaş arası nüfusun \%5'lik kısmı olan 247 milyon kişinin ise en az bir kez madde kullandığı belirtilmiştir [3]. Erkeklerde kadınlara göre, 15-24 yaş grubunda, 25 yaş üstüne göre madde kullanım yaygınlığı daha yüksek olduğu belirtilmektedir [4]. 2013 verilerinde en çok madde kullanım yaş aralığının 25-29 olduğu ancak ilk kez madde kullanma ve bağımlı olma yaşının ise 15-24 olduğu ifade edilmektedir [5]. 2016 yılı 15-64 yaş grubundaki her 100 kişi için bağımlılık oranı \%47,2'dir [6].

Üniversite yılları, ergenliğin karmaşasına ek olarak evden ve aileden ayrılma, yeni bir çevreye uyum, bir mesleğe aday olma ve iş bulmaya ilişkin belirsizlikler gibi birçok sorunların olduğu yıllardır. Sorunların yoğunluğu, gerçekçi olmayan beklentilerin çokluğu, sosyal desteklerin yetersizliği, gençlerin doğru değerlendirmeler yapmalarını engellemekte ve bir takım problemlerin ortaya çıkmasına sebep olmaktadır. Bu sorunlara bağlı olarak gelişen stresin üniversite öğrencilerinde tütün, alkol ve madde kullanımını artırdığı ileri sürülmektedir $[1,7,8]$.

Gençlerin sigara, alkol ve uyuşturucu madde kullanımına zemin hazırlayan çok sayıda risk etkeni tanımlanmaktadır. Bu risk etkenlerinden bir veya birkaçını taşıyan gençlerin madde bağımlısı olma riskinin yüksek olduğu belirtilmektedir. Alanyazındaki çalışmalarda madde kullanımının cinsiyet [9, 10], anne-baba tutumları [11] ailede sigara-alkol kullanımı [1], akran etkisi [12], dini inanç [13], mükemmeliyetçilik [14], benlik imajı [15], kimlik gelişimi [16], akademik başarı [17], ebeveyne bağlanma [18], yaşam amaçları [19] ve stresle başetme yöntemleri gibi risk etkenleri olduğu belirtilmektedir.

Hemşirelik öğrencileri gerek eğitim ve uygulama sürecinde gerekse biyopsikososyal gelişim sürecinde karşılaştıkları travmatik ve stresli yaşantılardan dolayı engellenmişlik, incinme ve hayal kırıklıkları yaşayabilmektedir [20, 21]. Hemşirelik öğrencileri ayrıca eğitimlerinden ve hastane ortamından kaynaklanan bir takım stresörlerle karşılaşmaktadırlar. Bunlar genç yaşta sağlık problemi olan insanlarla yoğun ve teke tek iletişime girmeleri; acı çekme, ağrı, ümitsizlik gibi olumsuz duygularla sık sık karşılaşmaları; eğiticisine karşı hasta bakımından sorumlu gençler olmaları, yoğun ders programları ve buna bağlı sosyal aktivitenin düşük olması gibi stresörlerdir [20].

Bireyler stresörlerle karşı karşıya geldiklerinde mücadele etmeye çabalarlar. $\mathrm{Bu}$ durumda stresle başa çıkma kavramı ortaya çıkar. Stresle başa çıkma kişinin kaynaklarını aşan ya da zorlayan spesifik iç ve dış talepler arasındaki çatışmaları yönetmek için dinamik, bilişsel, duygusal ve davranışsal çabalardır [22]. Bilim insanları stresle başa çıkmayı farklı şekillerde tanımlamışlardır. Folkman ve Lazarus [23] problem odaklı başa çıkma (problemi çözmek için doğrudan faaliyette bulunma ya da çözüm için gerekli bilgiyi elde etmedir) ve duygu odaklı başa çıkma (strese karşı olumsuz duyguları azaltma çabalarıdır) olarak iki gruba ayırırlar. Billings ve Moos [24] başa çıkmayı; problem odaklı başa çıkma olan aktif bilişsel, aktif davranışsal ve duygu odaklı başa çıkmanın bir şekli olan kaçma olarak üç faktör ile kavramsallaştırmıştır. Şahin ve Durak [25] ise bireyin stresle başa çıkmasında beş farklı yaklaşım olduğunu belirtmiştir. Bunlar; kendine güvenli yaklaşım, çaresiz yaklaşım, boyun eğici yaklaşım, iyimser yaklaşım ve sosyal desteğe başvurmadır.

Hemşirelerin öğrenci oldukları dönemde stresle başetme ve madde kullanımı ile ilgili 
yeterli bilgi ve donanımına sahip olmaları gelecekte stresle başetme yöntemlerini ve madde kullanım durumlarını etkileyebilecektir. Eğitimleri süresince kendilerini doğru şekilde ifade edebilmelerini, streslerini yönetebilmelerini, öfke duygularını uygun şekilde ifade etmelerini, yaşanabilecek çatışmaları doğru şekilde çözmelerini, kendileri ile ilgili planlarını bağımsızca uygulayabilmelerini sağlayabilecektir. Buna ek olarak mesleklerini uygularken stresle başetme yöntemlerinden etkili olanları kullanmaları, sosyal ve mesleki yaşamda daha mutlu, kaliteli, kendilerini sürekli geliştiren insanlar olabilmelerini sağlayacaktır. Türkiye'de yapılan çalışmalarda hemşirelik öğrencilerinde stresle başetme yöntemleri ve madde kullanım durumları ayrı ayrı araştırılmıştır. Burada öğrenci hemşirelerin hem stresle başetme hem de madde kullanım durumlarının birlikte ele alınmış olması açısından önemli bir çalışma olduğu düşünülmektedir.

$\mathrm{Bu}$ çalışmanın amacı hemşirelik öğrencilerinin stresle başetme durumları ve madde kullanım öykülerini belirlemektir.

\section{Araştırma Soruları:}

1. Hemşirelik öğrencilerinin stresle başetme durumları nasıldır?

2. Hemşirelik öğrencilerinin madde kullanım öyküleri nasıldır?

3. Hemşirelik öğrencilerinin sosyodemografik özelliklerine göre stresle başetme durumları nasıldır?

4. Hemşirelik öğrencilerinin madde kullanım durumlarına göre stresle başetmeleri nasıldır?

\section{Gereç ve yöntem}

\section{Araştırmanın evreni ve örneklemi}

Tanımlayıcı türdeki araştırmanın verileri 2016-2017 Eğitim-Öğretim Bahar döneminde toplanmıştır. Araştırma merkezi Denizli'dir. Araştırmanın evrenini 2016-2017 EğitimÖğretim Bahar döneminde bir üniversitenin sağlık bilimleri fakültesi hemşirelik bölümünde 1., 2., 3., 4. sınıfta öğrenim gören toplam 700 öğrenci oluşturmuştur. Örneklem büyüklüğünün hesaplanmasında evreni bilinen örneklem yöntemi uygulanmış ve örneklem aşağıda verilen formülle hesaplanmıştır [26]. Buna göre örneklem sayısı \%95 güven aralığında
248 öğrenci olarak tespit edilmiştir. Kayıpların olabileceği düşünülerek 371 öğrenciye ulaşılmış fakat kayıp olmadığı ve veri toplama araçlarını eksiksiz dolduran 371 öğrenci araştırmanın örneklemini oluşturmuştur. Uygulamanın yapıldığı gün gelen ve çalışmaya katılmayı kabul eden hemşirelik öğrencileri araştırmanın dahil olma kriteri olarak tespit edilmiştir.

\section{$n=N t^{2} p q / d^{2}(N-1)+t^{2} p q$}

\section{N=Evren büyüklüğü (700)}

$\mathrm{t}=$ Belirli serbestlik derecesinde ve saptanan yanılma düzeyinde $t$ tablosunda bulunan teorik değer ( $\alpha=0,05$ serbestlik derecesindeki $t=1,96$ ).

p=İncelenecek olayın görülüş sıklığı (2016 yılı 15-64 yaş grubundaki her 100 kişi için bağımlılık oranı \%47,2) [6]. p).

q=İncelenecek olayın görülmeyiş sıklığı (1-

d=Olayın görülüş sıklığına göre yapılmak istenen \pm sapma $(0,05)$.

\section{Veri toplama araçları}

Veriler literatür bilgileri doğrultusunda araştırmacılar tarafından oluşturulan anket formu, Stresle Başetme Tarzları Ölçeği (SBTÖ) ile toplanmıştır.

Anket Formu: Araştırmacılar tarafından oluşturulan anket formu öğrencilerin sosyodemografik özelliklerine ait bilgileri içeren 30 soru, sigara, alkol ve bağımlılık yapıcı madde kullanımına ait bilgileri içeren 13 soru olmak üzere toplam 43 sorudan oluşmaktadır.

Stresle Baş Etme Tarzları Ölçeği (SBTÖ): Folkman ve Lazarus [23] tarafından geliştirilen SBTÖ'nün (Ways of Coping Inventory) ülkemiz için geçerlik güvenirlik çalışması Şahin ve Durak [25] tarafından yapılmıştır. Bu ölçek kendine güvenli yaklaşım, iyimser yaklaşım, kendine güvensiz/çaresiz yaklaşım, boyun eğici yaklaşım ve sosyal destek arama olarak 5 alt boyutlardan oluşmaktadır. Toplam 30 maddeden oluşan, 0-3 arasında puanlanan bu ölçekte, sosyal desteğe başvurmanın hesaplanmasında 1 . ve 9. maddeler ters puanlanarak hesaplanmaktadır. Her faktöre ait puanlar ayrı ayrı hesaplanmakta, toplam puan ise hesaplanmamaktadır. Ölçekte stresle etkili olarak başa çıkabilenlerin "Kendine güvenli" 
ve "İyimser yaklaşımı", başa çıkamayanların ise "Boyun eğici" ve "Çaresiz yaklaşımı" daha fazla kullandıkları ifade edilmektedir. Puanların yüksekliği, kişinin o tarzı daha çok kullandığını göstermektedir.

Ölçeğin alt boyutlarının içerdiği maddeler ve cronbach alpha değerleri: Kendine güvenli yaklaşım (KGY) (8, 10, 14, 20, 23, 26), 68; iyimser yaklaşım (İY) $(2,4,6,12,18), 57$; kendine güvensiz/çaresiz yaklaşım (KGÇY) $(3,7,11,19$, 22, 25, 27, 28), 76; boyun eğici yaklaşım (BEY) $(5,13,15,17,21,24), 76$; sosyal destek arama (SDA) (1, 9, 29, 30), 58'dir. Bu çalışmanın Cronbach's Alpha değerleri ise KGY, 76; IY, 68; KGÇY, 75; BEY, 67; SDA, 57'dir.

\section{Verilerin toplanması}

Veri toplama araçları öğrencilerin uygun olduğu ders saatlerinde çalışmayı kabul eden öğrencilere uygulanmış ve formları kendileri doldurmuştur. Veri toplamadan önce katılımcılara araştırma hakkında bilgi verilmiş ve onamları alınmıştır. Formların doldurulması yaklaşık 25 dakika sürmüştür.

\section{İstatistiksel analizler}

Verilerin analizinde SPSS 18.0 paket programı kullanılmıştır. Verilerin tanımlanmasında sayı, yüzde, ortalama, standart sapma değerleri kullanılmıştır. Ölçeğin güvenilirliğini belirlemede Cronbach alfa katsayısı kullanılmıştır. Veriler normal dağıım gösterdiği için bağımsız iki grup arasındaki fark için Student t-testi, ikiden fazla grup olması durumunda gruplar arası karşılaştırmalarda Tek yönlü Varyans Analiz (ANOVA) testi kullanılmıştır. İstatistiksel anlamlılık ise $p<0,05$ ile tanımlanmıştır.

\section{Araştırmanın etik yönü}

Araştırma kapsamına alınanların sözel onamları alınmıştır. Pamukkale Üniversitesi Girişimsel Olmayan Klinik Araştırmalar Etik Kurulu'ndan 20.04.2017 tarihinde 60116787020/26147 sayılı karar ile yazılı izin alınmıştır. Araştırmanın yapıldığı kurumdan da yazılı izin alınmıştır.

\section{Bulgular}

Çalışma kapsamına alınan öğrencilerin

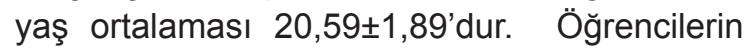
\%53,6'sı 18-20 yaş aralığında, çoğunluğu
$(\% 79,2)$ kadın ve $\% 34,5$ 'i 1 . sınıftır. Çalışmaya alınanların \%35,6'sı devlet yurdunda kalmakta, büyük çoğunluğu $(\% 90,3)$ çekirdek aile yapısında, \%80,9'unun annesi ve \%81,4'ünün babası çalışmaktadır. Öğrencilerin \%37,2'si anne tutumunu ve \%39,9'u baba tutumunu demokratik-katılımcı olarak belirtmiştir. Öğrenciler aile içi iletişimlerini ve çevre ile olan iletişimlerini büyük oranda (sırasıyla $\% 82,7, \% 83,0)$ iyi olarak değerlendirmektedir. Yarısından fazlası $(\% 63,3)$ kendini pozitif (iyimser, kendini seven, umutlu) birey olarak ifade etmesine rağmen, \%87,6'sı yaşamını olumsuz değerlendirmiştir. Öğrencilerin \%52,9'u okul ortamının stresli olduğunu belirtirken, \%47,1'i okul ortamının stresli olmadığını belirtmiştir. Öğrencilerin \%27,0'si okul ortamındaki stresin sınavlar, dersler, ders işleme şeklinden kaynaklandığını belirtirken, \%15,4'ü stajlar, olumsuz hoca yaklaşımdan kaynaklandığını ifade etmiştir (Tablo 1).

Katılımcıların \%64,7'si hayatlarında hiç sigara kullanmadıklarını, \%81,7'si şu an sigara kullanmadıklarını ve \%18,3'ü ise şu an sigara kullandıklarını ifade etmiştir. İlk sigara kullananların $(\% 35,3) \quad \% 22,7$ 'si $15-18$ yaş arasında ve merak ettikleri için $(\% 24,5)$ sigaraya başladıklarını ifade etmişlerdir. Öğrencilerin \%66,6'sı hayatlarında hiç alkol almadıklarını belirtmiştir. Hayatlarında en az bir kez alkol kullananların $(\% 33,4)$ ilk alkol kullanma yaşı 1518 yaş arasında $(\% 22,5)$ olduğu saptanmıştır. Çalışmaya alınanlar İlk alkolü kuzen/arkadaş ile $(\% 27,0)$ birlikte ve merak-heves $(\% 27,8)$ nedeniyle aldıklarını ifade etmiştir. Öğrencilerin \%83,0'ü şu anda alkol kullanmadıklarını ifade ederken, \%17,0'si şu anda alkol kullandığını belirtmiştir. Öğrencilerin tamamına yakını $(\% 99,5)$ sigara ve alkol dışında herhangi bir bağımlılık yapıcı madde kullanmadıklarını belirtmiştir (Tablo 2). Bu bulgulara göre hemşirelik öğrencilerinin madde kullanımlarının yüksek olmadığı belirlenmiştir.

Öğrencilerin stresle başetme tarzları ölçeği puan ortalamalarının dağılımı Tablo 3'te ayrıntılı olarak görülmektedir. Bu çalışmada öğrenciler stresle başa çıkmada en fazla sorunlar karşısında etkili olan KGY, ardından etkisiz olan KGÇY kullandıkları ve en az olarak da etkisiz olan BEY'i kullandıkları saptanmıştır. $\mathrm{Bu}$ veriler doğrultusunda çalışmada hemşirelik öğrencilerinin stresle başetme durumlarının etkili olduğu belirlenmiştir. 
Tablo 1. Öğrencilerin ta tanımlayıcı özelliklerine göre dağıımı $(n=371)$.

\begin{tabular}{|c|c|c|}
\hline Tanımlayıcı özellikler & $\mathbf{n}$ & $\%$ \\
\hline \multicolumn{3}{|l|}{ Yaş } \\
\hline $18-20$ & 199 & 53,6 \\
\hline 21 ve üzeri & 172 & 46,4 \\
\hline \multicolumn{3}{|l|}{ Cinsiyet } \\
\hline Kadın & 294 & 79,2 \\
\hline Erkek & 77 & 20,8 \\
\hline \multicolumn{3}{|l|}{ Sınıflar } \\
\hline 1. sınıf & 128 & 34,5 \\
\hline 2. sinıf & 93 & 25,1 \\
\hline 3. sinıf & 61 & 16,4 \\
\hline 4. sınıf & 89 & 24,0 \\
\hline \multicolumn{3}{|l|}{ Şu an yaşadığı yer } \\
\hline Ailesiyle & 113 & 30,5 \\
\hline Devlet yurdu & 132 & 35,6 \\
\hline Özel yurt & 26 & 7,0 \\
\hline Akrabalarıyla & 80 & 21,6 \\
\hline Arkadaşlarıyla & 20 & 5,4 \\
\hline \multicolumn{3}{|l|}{ Aile yapısı } \\
\hline Çekirdek aile & 335 & 90,3 \\
\hline Geniş aile & 19 & 5,1 \\
\hline Parçalanmış aile & 17 & 4,6 \\
\hline \multicolumn{3}{|l|}{ Anne tutumu } \\
\hline Katı-kuralcı & 16 & 4,3 \\
\hline Aşırı koruyucu & 111 & 29,9 \\
\hline Soğuk ilgisiz & 24 & 7,1 \\
\hline Başkalarıyla karşılaştırıcı & 31 & 8,4 \\
\hline Denetleyici & 49 & 13,2 \\
\hline Demokratik katılımcı & 138 & 37,2 \\
\hline \multicolumn{3}{|l|}{ Baba tutumu } \\
\hline Katı-kuralcı & 46 & 12,4 \\
\hline Aşırı koruyucu & 54 & 14,6 \\
\hline Soğuk ilgisiz & 29 & 7,8 \\
\hline Başkalarıyla karşılaştırıcı & 39 & 10,5 \\
\hline Denetleyici & 55 & 14,8 \\
\hline Demokratik katılımcı & 148 & 39,9 \\
\hline \multicolumn{3}{|l|}{ Aile ile iletişim } \\
\hline Kötü & 64 & 17,3 \\
\hline \multicolumn{3}{|l|}{ Çevre ile iletişim } \\
\hline İyi & 308 & 83,0 \\
\hline Kötü & 63 & 16,9 \\
\hline \multicolumn{3}{|l|}{ Kendini tanımlama durumu } \\
\hline $\begin{array}{l}\text { lyimser, kendini seven pozitif, umutlu, yardımsever } \\
\text { Ne olumlu ne olumsuz }\end{array}$ & $\begin{array}{l}235 \\
35\end{array}$ & $\begin{array}{l}63,3 \\
9,4\end{array}$ \\
\hline Hırslı, mükemmelliyetçi & 53 & 14,3 \\
\hline Sessiz, içine kapanık & 8 & 2,2 \\
\hline Olumsuz, karamsar ve sabırsız & 40 & 10,8 \\
\hline \multicolumn{3}{|l|}{ Okul Ortamındaki Stres Nedenleri } \\
\hline Stres belirtmeyenler & 175 & 47,2 \\
\hline Sınavlar, dersler, ders işleme şekli & 100 & 27,0 \\
\hline Sınıfların kalabalıklılığı ve havasızlığı & 19 & 5,1 \\
\hline İnsanların birbirini ötekileştirmesi & 20 & 5,4 \\
\hline Stajlar, hoca yaklaşımının olumsuz olması & 57 & 15,4 \\
\hline
\end{tabular}


Yaşamı Değerlendirme

Olumlu

Olumsuz
46

325
12,4

87,6

Tablo 2. Öğrencilerin sigara-alkol ve bağımlılık yapıcı madde kullanımına ilişkin bulguları ( $n=371)$.

\begin{tabular}{|c|c|c|}
\hline Sigara-alkol ve bağımlılık yapıcı madde kullanımına ilişkin özellikler & $\mathbf{n}$ & $\%$ \\
\hline \multicolumn{3}{|l|}{ Hayatlarında sigara kullanma durumları } \\
\hline Hiç sigara kullanmadım & 240 & 64,7 \\
\hline Sigara kullandım & 131 & 35,3 \\
\hline \multicolumn{3}{|l|}{ İlk sigarayı kullanma yaşları } \\
\hline Sigara kullanmadım & 240 & 64,7 \\
\hline 15 yaş altı & 20 & 4,2 \\
\hline $15-18$ yaş & 80 & 22,7 \\
\hline $19-22$ yaş & 31 & 8,4 \\
\hline \multicolumn{3}{|l|}{ Şu anda sigara kullanma durumları } \\
\hline Kullanmıyorum & 303 & 81,7 \\
\hline Kullanıyorum & 68 & 18,3 \\
\hline \multicolumn{3}{|l|}{ Hayatlarında alkol kullanma durumları } \\
\hline Hiç alkol kullanmadım & 247 & 66,6 \\
\hline Alkol kullandım & 124 & 33,4 \\
\hline \multicolumn{3}{|l|}{ İlk alkolü kullanma yaşları } \\
\hline Hiç alkol kullanmadım & 247 & 66,6 \\
\hline 15 yaş altı & 17 & 3,1 \\
\hline $15-18$ yaş & 78 & 22,5 \\
\hline $19-22$ yaş & 29 & 7,8 \\
\hline \multicolumn{3}{|l|}{ Şu anda alkol kullanma durumları } \\
\hline Kullanmıyorum & 308 & 83,0 \\
\hline Kullanıyorum & 63 & 17,0 \\
\hline \multicolumn{3}{|l|}{$\begin{array}{l}\text { Sigara ve alkol dışında herhangi bir bağımlılık yapıcı madde kullanma } \\
\text { durumları }\end{array}$} \\
\hline Kullanmadım & 369 & 99,5 \\
\hline Kullandım & 2 & 0,5 \\
\hline
\end{tabular}

Tablo 3. Öğrencilerin stresle başetme tarzları ölçeği puan ortalamalarının dağılımı $(n=371)$.

\begin{tabular}{lcc}
\hline Alt Ölçek Puan Ortalamaları & $\mathrm{X} \pm \mathrm{SS}$ & Min-Max \\
\hline Kendine Güvenli Yaklaşım (KGY) & $12,61 \pm 4,01$ & $2-27$ \\
Kendine Güvensiz/Çaresiz Yaklaşım (KGÇY) & $11,95 \pm 4,55$ & $0-24$ \\
Boyun Eğici Yaklaşım (BEY) & $6,68 \pm 3,42$ & $0-18$ \\
Iyimser Yaklaşım (IY) & $8,38 \pm 2,87$ & $0-21$ \\
Sosyal Destek Arama (SDA) & $7,02 \pm 1,90$ & $2-16$ \\
\hline
\end{tabular}

KGY: Kendine güvenli yaklaşım; IY: lyimser yaklaşım; KGÇY: Kendine güvensiz/çaresiz yaklaşım; BEY: Boyun eğici yaklaşım; SDA: Sosyal destek arama 
Öğrencilerin bazı değişkenlere göre stresle başetme tarzları alt ölçek puan ortalamaları incelendiğinde; yaşa ve aile yapısına göre etkisiz olan KGÇY ve BEY, cinsiyete göre etkili olan IY, sınıflara göre etkisiz olan BEY, kaldığı yere göre SDA alt ölçek puan ortalamalarında istatistiksel olarak anlamlı olduğu saptanmıştır $(p<0,05)$ (Tablo $4 a)$. Bu bulgularla yaşı büyük olan ve aile yapısı geniş olan öğrencilerin, 3. sınıfların, aile dışında başka yerde kalan öğrencilerin stresle başetme tarzlarının etkisiz olduğu görülmektedir.

Annenin çalışma durumuna göre etkisiz olan $B E Y$ ve SDA; anne tutumuna göre etkisiz olan $B E Y$; öğrencilerin aile içi iletişimine ve çevre ile iletişimine göre etkili olan KGY ve IY, etkisiz olan KGÇY; kendisini tanımlama durumuna göre etkili olan KGY ve IY, etkisiz olan KGÇY ve $\mathrm{BEY}$ alt ölçek puan ortalamalarında istatistiksel olarak anlamlı bir farklılık bulunmuştur $(p<0,05)$ (Tablo 4b). Bu verilerle annesi çalışmayanların, aşırı koruyucu, soğuk, ilgisiz ve denetleyici anne tutumları olanların, aile içi ve çevre ile iletişimlerini kötü olarak belirtenlerin, kendini sessiziçine kapanık, olumsuz, karamsar, sabırsız değerlendirenlerin stresle başetmelerinin etkisiz olduğu belirlenmiştir. Aile içi ve çevre ile olan iletişimini çok iyi değerlendirenlerin, kendini olumlu tanımlayanların stresle başetmelerinin etkili olduğu saptanmıştır.

Çalışma kapsamına alınanların ruh sağlığı probleminin varlığına, inanç ve yaşamını değerlendirme durumuna göre etkisiz olan KGÇY, sigara içme durumlarına göre etkisiz olan KGÇY, BEY ve SDA alt ölçek puan ortalamalarında istatistiksel olarak anlamlılık olduğu saptanmıştır $(p<0,05)$ (Tablo $4 \mathrm{c})$. Bu bulgularla ruh sağlığı problemi olduğunu belirtenlerin, İnançsız olduğunu bildirenlerin, yaşamını olumsuz değerlendirenlerin ve sigara kullananların stresle başetmelerinin etkisiz olduğu belirlenmiştir. Bu doğrultuda hemşirelik öğrencilerinin sosyodemografik özelliklerine ve özellikle sigara kullanmalarına göre stresle başetme durumları arasında anlamlı bir ilişki olduğu saptanmıştır.

\section{Tartışma}

Stres, eğitim sürecinde akademik performansı ve öğrenci refahını etkileyebilecek önemli bir psikososyal faktördür. Hemşirelik öğrencileri teorik derslerde ve klinik uygulamada hastalarla çalışırken birçok stresörle karşı karşıya kalmaktadır. Hemşirelik öğrencilerinin stresle başetme durumları ve madde kullanım öykülerini belirlemeyi amaçlayan bu çalışmada katıımcıların yaş ortalaması 20,59'dur. Bu yaş döneminde yaşanabilecek stresler eğer iyi yönetilemezse madde kullanımı gibi olumsuz sonuçlar doğurabilmektedir.

Araştırma kapsamına giren öğrencilerin çoğunluğu kadın ve aileleri çekirdek aile yapısındadır. Çevre ve aile ile olan iletişimlerini büyük oranda iyi olarak değerlendirmişlerdir. Yarısından fazlası kendisini pozitif birey ve yaşamının olumlu olduğunu ifade etmiştir.

Çocuk dünyaya geldiği anda ilk etkileşimde bulunduğu kişiler aile bireyleri ve özellikle annebabasıdır. Bu etkileşim çocuğun tüm yaşamı boyunca devam eder. Çocuğun kişilik yapısının oluşmasında anne-baba etkisinin önemli bir yeri ve değeri vardır. Uyumlu ve özgür bir ailede, tutarlı ve sağlıklı ilişkiler içinde yetişen çocuk, özerk bir birey olarak yetişkin yaşamına ulaşabilir [27]. Çocuk, kültürel değerlerini, temel alışkanlıklarını gelişim görevlerine karşı yaklaşımlarını aile ortamında kazanır. Çocuğun olumlu bir benlik tasarımı oluşturmasında yeterlilik duygusu kazanmasında anne-babası ile etkileşiminde aldığı geri bildirimler çok önemli rol oynar [28]. Bu çalışmada anne baba tutumu demokratik-katılımcı olarak belirlenmiştir. Bu tutum aile üyelerinin gereksinimlerine odaklı, bireylerin kendini ifade etmesine teşvik eden ve yaşının gerektirdiği şekilde karar verme sorumluluğu olan önemli bir tutumdur. Bu çalışmada öğrencilerin stresle başetmesinde en çok etkili yöntem olan KGY kullanmalarında aile tutumunun oldukça etkili olabileceği düşünülmektedir.

Öğrencilerin \%27,0'si okul ortamındaki stresin sınavlar, dersler, ders işleme şeklinden kaynaklandığını belirtirken, ardından $\% 15,4$ 'ü stajlar, olumsuz hoca yaklaşımdan kaynaklandığını belirtmiştir. Yapılan bazı çalışmalarda bu bulguyu destekler niteliktedir $[29,30]$.

Yapılan bu çalışmada öğrencilerin \%18,3'ü şu an sigara kullandıklarını belirtmişlerdir. Mavili'nin [31] çalışmasında 18,8, Çapık ve Cingil'in [32] yaptığı çalışmada oran \%12,9, Çapık ve Özbıçakcı'nın [33] bulgusunda \%17,5'dir. Erkeklerde kadınlara göre, madde kullanım 
Tablo 4a. Öğrencilerin bazı tanımlayıcı özelliklerine göre stresle başetme tarzları ölçeği puan ortalamalarının dağııımı.

\begin{tabular}{|c|c|c|c|c|c|}
\hline \multirow[b]{2}{*}{ Tanımlayıcı özellikler } & \multicolumn{5}{|c|}{ Ölçek alt boyutları } \\
\hline & $\begin{array}{l}\text { KGY } \\
\bar{X} \pm S S\end{array}$ & $\begin{array}{l}\text { iY } \\
\bar{X} \pm S S\end{array}$ & $\begin{array}{l}\text { KGÇY } \\
\overline{\mathbf{x}} \pm S S\end{array}$ & $\begin{array}{l}\text { BEY } \\
\bar{x} \pm S S\end{array}$ & $\begin{array}{l}\text { SDA } \\
\bar{x} \pm S S\end{array}$ \\
\hline \multicolumn{6}{|l|}{ Yaş } \\
\hline $18-20$ yaş $(n=199)$ & $12,33 \pm 4,11$ & $8,21 \pm 2,83$ & $11,42 \pm 4,57$ & $6,21 \pm 3,45$ & $6,98 \pm 1,78$ \\
\hline \multirow[t]{3}{*}{21 yaş ve üzeri $(n=172)$} & $12,94 \pm 3,87$ & $8,57 \pm 2,91$ & $12,55 \pm 4,47$ & $7,22 \pm 3,30$ & $7,06 \pm 2,02$ \\
\hline & $t=-1,462$ & $t=-1,218$ & $t=-2,399$ & $t=-2,880$ & $t=-, 403$ \\
\hline & $p=0,143$ & $p=0,224$ & $p=0,017$ & $p=0,004$ & $p=0,690$ \\
\hline \multicolumn{6}{|l|}{ Cinsiyet } \\
\hline Kadın $(n=294)$ & $12,43 \pm 4,06$ & $8,17 \pm 2,90$ & $12,07 \pm 4,58$ & $6,64 \pm 3,43$ & $6,96 \pm 1,83$ \\
\hline \multirow[t]{3}{*}{ Erkek $(n=77)$} & $13,31 \pm 3,77$ & $9,18 \pm 2,63$ & $11,48 \pm 4,47$ & $6,83 \pm 3,38$ & $7,25 \pm 2,14$ \\
\hline & $t=-1,716$ & $t=-2,772$ & $t=1,019$ & $t=-0,430$ & $t=-1,208$ \\
\hline & $p=0,087$ & $p=0,006$ & $p=0,309$ & $p=0,668$ & $p=0,228$ \\
\hline \multicolumn{6}{|l|}{ Sınıflar } \\
\hline 1. $\sin$ If $(n=128)$ & $12,17 \pm 4,04$ & $8,29 \pm 2,91$ & $11,19 \pm 4,41$ & $6,12 \pm 3,48$ & $6,95 \pm 1,66$ \\
\hline 2. $\sin I f(n=93)$ & $12,74 \pm 4,41$ & $8,12 \pm 2,92$ & $12,37 \pm 4,96$ & $6,27 \pm 3,22$ & $7,19 \pm 2,02$ \\
\hline 3. $\sin I f(n=61)$ & $13,14 \pm 3,14$ & $9,14 \pm 2,43$ & $12,70 \pm 4,00$ & $8,57 \pm 3,62$ & $7,34 \pm 1,87$ \\
\hline \multirow[t]{3}{*}{ 4. $\sin$ If $(n=89)$} & $12,74 \pm 4,06$ & $8,23 \pm 2,99$ & $12,07 \pm 4,60$ & $6,60 \pm 2,95$ & $6,74 \pm 2,08$ \\
\hline & $F=0,920$ & $F=1,805$ & $F=2,039$ & $F=8,254$ & $F=1,544$ \\
\hline & $p=0,431$ & $p=0,146$ & $p=0,108$ & $p=0,001$ & $p=0,203$ \\
\hline \multicolumn{6}{|l|}{ Şu Anda Kaldığı Yer } \\
\hline Aile yanında $(n=113)$ & $11,76 \pm 4,13$ & $8,00 \pm 3,10$ & $11,92 \pm 4,76$ & $6,35 \pm 3,49$ & $6,93 \pm 1,93$ \\
\hline Devlet yurdu (n=132) & $12,80 \pm 4,05$ & $8,34 \pm 2,76$ & $12,09 \pm 4,54$ & $6,43 \pm 3,22$ & $7,00 \pm 1,64$ \\
\hline Özel yurt (n=26) & $13,15 \pm 3,52$ & $8,88 \pm 2,00$ & $12,53 \pm 4,66$ & $6,96 \pm 3,09$ & $7,80 \pm 1,41$ \\
\hline Akraba yanında $(n=80)$ & $13,26 \pm 3,54$ & $8,71 \pm 2,87$ & $11,76 \pm 4,10$ & $7,47 \pm 3,64$ & $7,17 \pm 2,24$ \\
\hline \multirow[t]{3}{*}{ Arkadaş yanında $(n=20)$} & $12,90 \pm 4,94$ & $8,75 \pm 3,20$ & $11,15 \pm 5,29$ & $6,60 \pm 3,51$ & $6,10 \pm 2,04$ \\
\hline & $F=2,036$ & $F=1,027$ & $F=0,326$ & $F=1,557$ & $F=2,514$ \\
\hline & $p=0,089$ & $p=0,393$ & $p=0,861$ & $p=0,185$ & $p=0,041$ \\
\hline \multicolumn{6}{|l|}{ Aile Yapısı } \\
\hline Çekirdek aile (n=335) & $12,71 \pm 4,04$ & $8,42 \pm 2,91$ & $11,74 \pm 4,46$ & $6,56 \pm 3,38$ & $7,01 \pm 1,89$ \\
\hline Geniş aile $(n=20)$ & $11,47 \pm 2,69$ & $8,47 \pm 2,22$ & $14,68 \pm 4,00$ & $8,26 \pm 2,90$ & $7,47 \pm 1,67$ \\
\hline \multirow[t]{3}{*}{ Parçalanmış aile $(n=16)$} & $11,87 \pm 4,70$ & $7,56 \pm 2,68$ & $13,06 \pm 6,03$ & $7,68 \pm 4,07$ & $6,81 \pm 2,40$ \\
\hline & $F=0,762$ & $F=0,687$ & $F=2,919$ & $F=2,918$ & $F=0,517$ \\
\hline & $p=0,516$ & $p=0,561$ & $p=0,034$ & $p=0,034$ & $p=0,671$ \\
\hline
\end{tabular}

x:Ortalama; SS: Standart sapma; t: T Testi; F: One-Way Anova; KGY: Kendine güvenli yaklaşım; IY: lyimser yaklaşım; KGÇY: Kendine güvensiz/çaresiz yaklaşım; BEY: Boyun eğici yaklaşım; SDA: Sosyal destek arama 
Tablo 4b. Öğrencilerin bazı tanımlayıcı özelliklere göre stresle başetme tarzları ölçeği puan ortalamalarının dağııımı.

\begin{tabular}{|c|c|c|c|c|c|}
\hline \multirow[b]{2}{*}{ Tanımlayıcı özellikler } & \multicolumn{5}{|c|}{ Ölçek alt boyutları } \\
\hline & $\begin{array}{l}\text { KGY } \\
\overline{\mathbf{X}} \pm S S\end{array}$ & $\begin{array}{l}\text { iY } \\
\bar{x} \pm S S\end{array}$ & $\begin{array}{l}\text { KGÇY } \\
\overline{\mathbf{x}} \pm S S\end{array}$ & $\begin{array}{l}\text { BEY } \\
\bar{x} \pm S S\end{array}$ & $\begin{array}{l}\text { SDA } \\
\overline{\mathbf{x}} \pm S S\end{array}$ \\
\hline \multicolumn{6}{|l|}{ Annenin çalışma durumu } \\
\hline Çalışmıyor $(n=300)$ & $12,50 \pm 3,94$ & $8,53 \pm 2,86$ & $12,04 \pm 4,50$ & $685+346$ & $7,13 \pm 1,88$ \\
\hline \multirow[t]{3}{*}{ Çalışıyor $(n=71$} & $13,08 \pm 4,27$ & $7,73 \pm 2,85$ & $11,54 \pm 4,78$ & $\begin{array}{l}0,00 \pm 3,40 \\
5,95+3,16\end{array}$ & $6,56 \pm 1,89$ \\
\hline & $t=-0,598$ & $t=2,402$ & $t=0,717$ & $\begin{array}{l}5,95 \pm 3,10 \\
t=2,499\end{array}$ & $\mathrm{t}=2,186$ \\
\hline & $p=0,550$ & $p=0,017$ & $p=0,474$ & $\begin{array}{l}t=2,499 \\
p=0,013\end{array}$ & $p=0,030$ \\
\hline \multicolumn{6}{|l|}{ Anne tutumu } \\
\hline Katı-Kuralcı $(n=19)$ & $13,37 \pm 3,86$ & $7,43 \pm 2,73$ & $12,31 \pm 4,78$ & $5,56 \pm 3,82$ & $6,93 \pm 1,80$ \\
\hline Aşırı koruyucu $(n=114)$ & $12,26 \pm 3,89$ & $7,97 \pm 2,64$ & $12,43 \pm 4,46$ & $7,31 \pm 3,40$ & $7,07 \pm 1,76$ \\
\hline Soğuk, ilgisiz $(n=11)$ & $11,87 \pm 4,61$ & $7,25 \pm 3,65$ & $14,62 \pm 5,55$ & $7,25 \pm 3,88$ & $6,75 \pm 0,88$ \\
\hline Karşılaştırıcı $(n=34)$ & $13,22 \pm 4,43$ & $8,54 \pm 3,97$ & $11,80 \pm 4,51$ & $5,70 \pm 1,95$ & $6,54 \pm 2,26$ \\
\hline Denetleyici $(n=52)$ & $12,18 \pm 3,95$ & $8,22 \pm 2,71$ & $12,20 \pm 4,80$ & $7,12 \pm 3,89$ & $7,53 \pm 2,29$ \\
\hline \multirow[t]{3}{*}{ Demokratik $(n=141)$} & $12,92 \pm 4,06$ & $8,89 \pm 2,81$ & $11,23 \pm 4,38$ & $6,16 \pm 3,35$ & $7,01 \pm 1,75$ \\
\hline & $F=0,657$ & $F=1,649$ & $F=1,345$ & $F=2,500$ & $F=1,180$ \\
\hline & $p=0,685$ & $p=0,133$ & $p=0,236$ & $p=0,022$ & $p=0,316$ \\
\hline \multicolumn{6}{|l|}{ Aile içi iletişim } \\
\hline Çok iyi (n=95) & $13,32 \pm 4,27$ & $9,38 \pm 3,05$ & $11,17 \pm 4,91$ & $6,76 \pm 3,57$ & $7,07 \pm 2,02$ \\
\hline İyi $(n=212)$ & $12,60 \pm 3,84$ & $8,26 \pm 2,57$ & $11,79 \pm 4,12$ & $6,52 \pm 3,30$ & $7,06 \pm 1,86$ \\
\hline Ne iyi ne kötü (n=56) & $11,96 \pm 3,84$ & $7,75 \pm 2,90$ & $13,14 \pm 4,73$ & $6,98 \pm 3,66$ & $6,87 \pm 1,83$ \\
\hline \multirow[t]{3}{*}{ Kötü $(n=8)$} & $9,00 \pm 4,44$ & $3,87 \pm 2,23$ & $17,00 \pm 5,87$ & $7,62 \pm 3,11$ & $6,62 \pm 2,13$ \\
\hline & $F=3,729$ & $F=12,521$ & $F=5,756$ & $F=0,507$ & $F=0,279$ \\
\hline & $p=0,012$ & $p=0,001$ & $p=0,001$ & $p=0,67$ & $p=0,841$ \\
\hline \multicolumn{6}{|l|}{ Öğrencinin çevre ile iletişimi } \\
\hline Çok iyi $(n=75)$ & $13,45 \pm 3,72$ & $9,16 \pm 3,17$ & $11,04 \pm 4,40$ & $6,80 \pm 3,24$ & $7,06 \pm 1,88$ \\
\hline İyi $(n=233)$ & $12,79 \pm 4,01$ & $8,51 \pm 2,63$ & $11,92 \pm 4,51$ & $6,49 \pm 3,45$ & $6,98 \pm 1,91$ \\
\hline Ne iyi ne kötü (n=58) & $11,10 \pm 3,95$ & $7,03 \pm 2,97$ & $12,94 \pm 4,40$ & $7,18 \pm 3,26$ & $7,12 \pm 1,83$ \\
\hline \multirow[t]{3}{*}{ Kötü (n=5) } & $9,20 \pm 3,76$ & $5,80 \pm 1,78$ & $15,20 \pm 7,91$ & $7,60 \pm 6,02$ & $6,80 \pm 2,86$ \\
\hline & $F=5,377$ & $F=8,024$ & $F=2,814$ & $F=0,800$ & 0,188 \\
\hline & $p=0,001$ & $p=0,001$ & $p=0,039$ & $p=0,495$ & $p=0,904$ \\
\hline \\
\hline $\begin{array}{l}\text { İyimser, kendini seven pozitif, } \\
\text { umutlu, yardımsever }(n=235)\end{array}$ & $13,04 \pm 3,85$ & $8,85 \pm 2,67$ & $11,38 \pm 4,30$ & $6,59 \pm 3,52$ & $7,11 \pm 1,88$ \\
\hline Ne olumlu, ne olumsuz $(n=35)$ & $12,48 \pm 5,19$ & $8,20 \pm 2,86$ & $13,00 \pm 5,10$ & $7,54 \pm 3,31$ & $6,62 \pm 2,00$ \\
\hline Hırslı, mükemmelliyetçi $(n=53)$ & $13,15 \pm 3,61$ & $8,30 \pm 3,09$ & $11,62 \pm 4,67$ & $5,71 \pm 3,06$ & $6,98 \pm 1,59$ \\
\hline Sessiz, içine kapanık $(n=8)$ & $10,62 \pm 3,37$ & $7,75 \pm 2,65$ & $13,37 \pm 4,83$ & $9,62 \pm 3,85$ & $6,62 \pm 2,44$ \\
\hline \multirow{3}{*}{$\begin{array}{l}\text { Olumsuz, karamsar, sabırsız } \\
(\mathrm{n}=40)\end{array}$} & $9,90 \pm 3,30$ & $5,95 \pm 2,58$ & $14,50 \pm 4,45$ & $7,15 \pm 2,75$ & $7,00 \pm 2,17$ \\
\hline & $F=6,322$ & $F=9,753$ & $F=4,957$ & $F=3,404$ & $F=0,606$ \\
\hline & $p=0,001$ & $p=0,001$ & $p=0,001$ & $p=0,001$ & $p=0,658$ \\
\hline
\end{tabular}

X̃ Ortalama; SS:Standart sapma; t:T Testi; F: One-Way Anova; KGY: Kendine güvenli yaklaşım; IY: lyimser yaklaşım; KGÇY: Kendine güvensiz/çaresiz yaklaşım; BEY: Boyun eğici yaklaşım; SDA: Sosyal destek arama 
Tablo 4c. Öğrencilerin bazı tanımlayıcı özelliklere göre stresle başetme tarzları ölçeği puan ortalamalarının dağııımı.

\begin{tabular}{|c|c|c|c|c|c|}
\hline Tanımlayıcı özellikler & $\begin{array}{l}\text { KGY } \\
\bar{x} \pm S S\end{array}$ & $\begin{array}{l}\text { iY } \\
\bar{x} \pm S S\end{array}$ & $\begin{array}{l}\text { KGÇY } \\
\overline{\mathbf{x}} \pm S S\end{array}$ & $\begin{array}{l}\text { BEY } \\
\bar{x} \pm S S\end{array}$ & $\begin{array}{l}\text { SDA } \\
\bar{x} \pm S S\end{array}$ \\
\hline \multicolumn{6}{|l|}{ Ruh sağlığı problemi } \\
\hline Yok $(n=359)$ & $12,62 \pm 4,01$ & $8,40 \pm 2,84$ & $11,79 \pm 4,43$ & $6,67 \pm 3,43$ & $6,99 \pm 1,90$ \\
\hline \multirow[t]{3}{*}{$\operatorname{Var}(n=12)$} & $12,25 \pm 4,20$ & $7,75 \pm 3,86$ & $16,75 \pm 5,81$ & $7,00 \pm 2,98$ & $8,08 \pm 1,31$ \\
\hline & $t=0,319$ & $t=0,771$ & $t=-3,773$ & $t=-0,327$ & $t=-1,964$ \\
\hline & $p=0,750$ & $p=0,441$ & $p=0,001$ & $p=0,744$ & $p=0,050$ \\
\hline \multicolumn{6}{|l|}{ İnanç durumu } \\
\hline İnançsız $(n=12)$ & $10,83 \pm 3,27$ & $7,25 \pm 3,19$ & $15,00 \pm 5,46$ & $8,50 \pm 3,11$ & $7,08 \pm 2,27$ \\
\hline \multirow[t]{3}{*}{ İnançlı ( $n=359)$} & $12,67 \pm 4,02$ & $8,41 \pm 2,86$ & $11,84 \pm 4,49$ & $6,62 \pm 3,41$ & $7,02 \pm 1,89$ \\
\hline & $t=-1,566$ & $t=-1,385$ & $t=2,370$ & $t=1,878$ & $t=0,104$ \\
\hline & $p=0,118$ & $p=0,167$ & $p=0,018$ & $p=0,061$ & $p=0,917$ \\
\hline \multicolumn{6}{|c|}{ Yaşamını değerlendirmesi } \\
\hline Olumsuz $(n=46)$ & $12,04 \pm 4,00$ & $8,08 \pm 3,15$ & $14,19 \pm 4,76$ & $7,34 \pm 3,74$ & $7,06 \pm 2,16$ \\
\hline \multirow[t]{3}{*}{ Olumlu $(n=325)$} & $12,69 \pm 4,01$ & $8,42 \pm 2,83$ & $11,63 \pm 4,44$ & $6,58 \pm 3,36$ & $7,02 \pm 1,86$ \\
\hline & $t=-1,031$ & $t=-0,738$ & $t=3,626$ & $t=1,413$ & $t=0,146$ \\
\hline & $p=0,303$ & $p=0,461$ & $p=0,001$ & $p=0,159$ & $p=0,884$ \\
\hline \multicolumn{6}{|c|}{ Sigara kullanma durumları } \\
\hline Kullanmıyor ( $n=303)$ & $12,59 \pm 3,95$ & $8,39 \pm 2,82$ & $11,68 \pm 4,44$ & $6,47 \pm 7,61$ & $6,91 \pm 1,83$ \\
\hline \multirow[t]{3}{*}{ Kullanıyor (n=68) } & $12,69 \pm 4,28$ & $8,29 \pm 3,11$ & $13,13 \pm 4,87$ & $7,61 \pm 3,19$ & $7,52 \pm 2,13$ \\
\hline & $t=-0,174$ & $t=0,272$ & $t=-2,379$ & $t=-2,514$ & $t=-2,427$ \\
\hline & $p=0,862$ & $p=0,786$ & $p=0,018$ & $p=0,012$ & $p=0,016$ \\
\hline
\end{tabular}

x.:Ortalama; SS: Standart sapma; t: T Testi; F: One-Way Anova; KGY: Kendine güvenli yaklaşım; IY: lyimser yaklaşım; KGÇY: Kendine güvensiz/ çaresiz yaklaşım; BEY: Boyun eğici yaklaşım; SDA: Sosyal destek arama

yaygınlığı daha yüksek olduğu belirtilmektedir [4]. Bu çalışmada da değerin yüksek olması erkek hemşirelerin $\% 20,8$ oranında olmasından ve sigara kullanımının cinsiyet açısından erkeklerde daha yaygın görülmesinden kaynaklandığını düşündürmektedir.

Çalışmaya alınanların hayatlarında en az bir kez alkol alma oranları \%33,4'tür. Öğrenciler ilk alkol kullanma yaşının $15-18$ yaş $(\% 22,5)$ arasında olduğunu, arkadaşları ile birlikte ve merak-heves nedeni ile aldıklarını ifade etmişlerdir. Şu anda alkol kullananların oranı ise \%17,0'dir. Mavili [31], Koca ve ark. [34] hemşirelik öğrencileri ile ilgili yapmış oldukları çalışma bulguları bu çalışma bulgularıyla benzerlik göstermektedir.

Bu çalışmada ilk sigara ve alkol kullanmanın 15-22 yaş aralığında olduğu tespit edilmiştir. Bu bulguya paralel olarak TUBIM 2014 Raporu'na göre ilk kez madde kullanma ve bağımlı olma yaşı 15-24'tür. Bu rapora göre ilk maddeye başlama nedeni olarak merak, arkadaş etkisi ve aile sorunları nedeniyle başladıkları rapor edilmiştir [5]. Bu çalışmada da öğrenciler ilk sigara ve alkole başlama nedeni olarak (sigara
$\% 24,5$, alkol $\% 27,8$ ) merak-hevesten dolayı başladıklarını belirtmiştir.

Öğrencilerin tamamına yakını $(\% 99,5)$ sigara ve alkol dışında herhangi bir bağımlılık yapıcı madde kullanmadıklarını ifade etmiştir. $\mathrm{Bu}$ bulgunun aksine bağımlılık yapıcı madde kullanım oranları Koca ve ark. [34] yaptığı çalışmada \%2,2, Turhan ve ark. [1] çalışmasında en az bir kez uyuşturucu madde kullanımı \%9,6'dır. Bu çalışmada oranın düşük olmasının nedeni olarak çalışmaya alınan grubun annebaba tutumunun pozitif bir tutum olan demokratikkatıımcı olması, onların daha sağlıkı ve etkili başetme davranışı içerisinde olmalarına sebep olmuş olabilir. Ayrıca bu grubun sağlık okulunda okumuş olmaları, bağımlılık yapıcı madde ile ilgili farkındalıklarının ve bilgilerinin olmasından kaynaklanmış olabileceğini düşündürmektedir. $\mathrm{Bu}$ sonuç doğrultusunda bu çalışmada hemşirelik öğrencilerinin madde kullanım oranlarının yüksek olmadığı söylenebilir.

SBTÖ ölçeğinin alt boyutları değerlendirilirken; kendine güvenli ve iyimser alt boyutlarından alınan puanlar arttıkça stresle baş etmenin etkili olduğu; çaresiz yaklaşım ve 
boyun eğici yaklaşım alt boyutlarından alınan puanlar arttıkça ise stresle baş etmede etkisiz yöntemlerin kullanıldığı belirtilmektedir [25]. Bu çalışmada öğrencilerin stresle başa çıkmada en fazla etkili olan KGY kullandıkları belirlenmiştir. Yapılan bazı çalışmalarda bu bulguya paralel sonuçlar çıkmıştır [29, 35, 36]. Çalışmanın araştırma sorularından biri hemşirelik öğrencilerinin stresle başetme durumları nasııdır sorusuydu. Bu bulgu doğrultusunda öğrencilerin en fazla kendine güvenli yaklaşımı, en az olarak da boyun eğici yaklaşımları kullanıyor olmaları stresle başa çıkma konusunda etkili yöntemler kullandıklarını, stres yönetimi konusunda daha az sorun yaşadıklarını göstermektedir.

Öğrencilerin yaşa göre KGÇY ve BEY alt ölçek puan ortalamalarında istatistiksel olarak anlamlı bir farklıık olduğu, 21 ve üzeri yaş grubunun belirtilen bu puan ortalamalarında artma olduğu saptanmıştır. Razı ve ark'nın [37] yaptığı çalışmada da bizim elde ettiğimiz bulguyu destekler niteliktedir. Yaş arttıkça hemşirelik öğrencilerinin kaçıngan/çaresiz ve boyun eğici yaklaşımlarını sık kullanmalarının nedeni, daha önceki çabalarına rağmen yaşamlarındaki stresörleri azaltamamalarından, bu yaştakilerin sorumluluklarının daha farkında olmalarından, mezun olma ve atanma kaygılarından dolayı kaynaklanabileceğini düşündürmektedir.

$\mathrm{Bu}$ çalışmada cinsiyete göre iY alt ölçek puan ortalamasında istatistiksel olarak anlamlılık olduğu ve erkeklerin puan ortalamalarının yüksek olduğu belirlenmiştir. Yapılan çalışmalarda da bu bulguyu destekler sonuçlar bulunmaktadır. Literatürde başa çıkma tutumlarının cinsiyete bağlı olarak değişebildiği bildirilmektedir [38, 39]. Soderstrom ve ark. [40] kadınların duygu odaklı, erkeklerin ise problem odaklı yöntemleri daha sık kullandıklarını belirtmiştir. Otrar ve ark. [41] yaptığı bir çalışmada stresle başetmede kendine güvenli yaklaşım ve iyimser yaklaşım stratejilerini erkek öğrencilerin kadın öğrencilerden daha fazla kullandıkları belirtilmektedir.

Çalışmada sınıflara göre BEY alt ölçek puan ortalamalarında istatistiksel olarak anlamlı bir farklılık olduğu belirlenmiştir. 3. sınıf öğrencilerinin BEY puanlarının yüksek olduğu bulgulanmıştır. Bunun nedeni yoğun ders ve staj uygulamalarının öğrenci üzerinde oluşturduğu stres nedeniyle başetmeye çalışan öğrencinin 3 . sınıfa geldiğinde değişim görememesine bağlı olarak etkisiz yöntem olan boyun eğici yaklaşımı daha sık kullandıkları tahmin edilmektedir. Benzer şekilde Güler ve Çınar'ın [29] hemşirelik öğrencileri ile yaptığı çalışmada sınıflara göre boyun eğici yaklaşım ve sosyal destek arama puanlarında anlamlı bir fark bulunmuştur.

Şu anda kaldığı yere göre öğrencilerin SDA alt ölçek puan ortalamalarında istatistiksel anlamlılık olduğu, özel yurt ve akraba yanında kalanların SDA puan ortalamalarının yüksek olduğu belirlenmiştir. Bu da sosyal desteğin stresle başetmede önemli olduğunu göstermesi açısından önemli bir bulgudur. Sosyal desteği yeteri kadar alamayan öğrencilerde sosyal destek arama puanları daha yüksektir. Elde edilen bu sonuç aile ve arkadaş desteğinin stresle başetmede etkili olduğunu belirten bazı çalışmalarla aynı doğrultuda olduğu görülmektedir [30,42].

Katılımcıların bu çalışmada aile yapısına göre KGÇY ve BEY alt ölçek puanlarında istatistiksel olarak anlamlı bir farklılık olduğu görülmektedir. Geniş aile yapısına sahip bireylerin stresle başetme durumlarında etkisiz yöntemlerden KGÇY ve BEY puanlarının daha yüksek olduğu ve dolayısıyla bu yöntemleri daha çok kullandıkları görülmektedir. Türksoy'un [43] hemşirelik öğrencileri ile yapmış olduğu çalışmada da benzer sonuç çıkmıştır. Öğrencilerin daha kaçıngan ve boyun eğici yaklaşımda bulunmalarının nedeni olarak, geniş ailede yaşayan bireylerin bireysel olarak söz sahibi olamamalarından, kendilerini rahat ifade edememelerinden ve daha çok büyüklerin söz sahibi olmasından kaynaklandığı tahmin edilmektedir.

Öğrencilerin annenin tutumuna göre BEY alt ölçek puan ortalamalarında istatistiksel olarak anlamlılık olduğu ve annesinin tutumunu aşırı koruyucu olarak değerlendirenlerin puanlarının daha yüksek olduğu belirlenmiştir. Aşırı koruyucu ebeveyn tutumunda, ailenin çocuğa gerektiğinden fazla kontrol ve özen göstermesi söz konusudur. Bu tutumla yetiştirilen çocuklar, kendine güveni olmayan, sosyal ilişkilerde pasif, diğer kimselere bağımlı, çekingen, duygusal kırıklıkları olan çocuklar olmaktadır. Yetişkinliğinde ise stresle baş etme konusunda zorluk yaşayan ve beşetmede etkisiz yöntemler kullanan bireyler olacaktır [44]. 
Gençlerin aile içi ve çevre ile olan iletişiminin kötü olması onları stresle başetmede etkili olmayan sigara, alkol ve madde kullanımı gibi davranışlara yöneltmektedir [45]. Çalışmada aile içi iletişim ve çevre ile olan iletişim durumuna göre KGY, IY ve KGÇY puan ortalamalarında istatistiksel olarak anlamlılık olduğu saptanmıştır. İletişimini çok iyi ve iyi olarak değerlendirenlerin KGY ve İY puanlarının yüksek olduğu, kötü olarak değerlendirenlerin ise KGÇY puanlarının yüksek olduğu belirlenmiştir. Türksoy'un [43] yaptığı çalışmada hemşirelik öğrencilerinin aile içi iletişim durumlarının stresle başetmede değişiklik oluşturabileceğini belirtmiş ve bu çalışmaya paralel bulgular saptamıştır. Bu bulgu stres yönetiminde aile yaklaşımının ve çevre ile olan iletişimin oldukça önemli olduğunu göstermektedir. Kişinin sorunlara karşı bakışını ve başetmesini ailedeki yaklaşımlar ve onların model alınması doğrultusunda çocuk hayata karşı duruşunu belirlemektedir. Bu nedenle stresle başetmede aile ve çevrenin güçlendirilmesi açısından önemli bir bulgudur.

$\mathrm{Bu}$ çalışmada kendisini tanımlama durumuna göre KGY, IY, KGÇY ve BEY alt ölçek puanlarında istatistiksel düzeyde anlamlı bir farklılık bulunmuştur. Kendisini iyimser, kendini seven pozitif, umutlu, yardımsever olarak tanımlayanların stres yönetiminde etkili olan KGY ve IY puanlarının yüksek olduğu; olumsuz, karamsar, sabırsız olarak tanımlayanların ise stres yönetiminde etkisiz olan KGÇY ve BEY puanlarının daha yüksek olduğu görülmektedir. Strese neden olan etkenler ve stres yönetiminde kişilik özelliğinin ve kişinin kendisini algılamasının etkili olduğu belirtilmektedir. Olumlu ve pozitif kişiliklerin stres yönetiminde etkili yöntemler kullandıkları, olumsuz bakış açısına sahip olanların ise stres yönetiminde etkisiz olan yöntemler uyguladıkları belirtilmektedir [22, 46, 47]. Bu çalışmadan elde edilen veri literatür bilgisi ile uyuşmaktadır.

Stresle başaçıkma tarzları da, ruh sağlığı acısından koruyucu rol oynamaktadır. Bazı tarzlar, bireyi stresli yaşam olaylarından uzak tutmakta, bazıları ise ruhsal bozukluklara karşı bireyin duyarlıı̆̆ını arttırmaktadır. Yapılan çalışmalarda daha önce ruh sağlığı problemi olanların stres yönetiminde sorun yaşayabileceği belirtilmektedir [48-51]. Yapılan bu çalışmada öğrencilerin ruh sağlığı probleminin varlığına göre KGÇY ölçek puan ortalamalarında istatistiksel olarak anlamlılık olduğu ve ruh sağlığı problemi olduğunu belirtenlerin KGÇY puanlarının daha yüksek olması literatür bilgisi ile uyuşmaktadır.

Çalışmada inanç durumuna göre etkisiz yöntem olan KGÇY alt ölçek puanında istatistiksel anlamlılık olduğu ve kendini inançsız değerlendirenlerin puan ortalamalarının yüksek olduğu saptanmıştır. İnancın ve dua etmenin stresle başetme yöntemi olarak kullanıldığı ve bireyin üzerinde olumlu etkisi olduğu belirtilmektedir $[52,53]$.

Öğrencilerin sigara içme durumlarına göre stresle başetme tarzlarında etkisiz olan KGÇY, $B E Y$ ve SDA alt ölçek puan ortalamalarında istatistiksel olarak anlamlılık olduğu ve sigara içenlerin içmeyenlere göre puanlarının daha yüksek olduğu bulgulanmıştır. Bizim bulgumuz doğrultusunda literatürde madde kullanan kişilerin, uygun alternatif başa çıkma yollarını kullanamadıkları, kaçınan ve etkili olmayan başa çıkma mekanizmaları kullandıkları belirtilmektedir $[54,55]$.

Sonuç olarak;

Öğrencilerin büyük çoğunluğunun şu an sigara kullanmadığı, yarısından fazlasının hiç alkol almadığı ve büyük çoğunluğunun sigaraalkol dışında herhangi bir bağımlılık yapıcı madde kullanmadıkları saptanmıştır.

Çalışmaya alınan öğrencilerin yaşa, cinsiyete, sınıflara, şu an yaşadığı yere, aile yapısına, annenin çalışmasına, anne tutumuna, aile içi iletişime, kendilerinin çevre ile olan iletişimine, kendini tanımlama durumuna, ruh sağlığı probleminin varlığına, inançlarına, yaşamlarını değerlendirmelerine, şu anda sigara içme durumuna göre stresle başetme tarzları alt ölçeklerinde istatistiksel olarak anlamlı bir fark belirlenmiştir.

Öğrencilerin medeni ve çalışma durumuna, aylık kişisel ve ailenin gelirlerine, kardeş sayısına, sağlık güvencesine, en uzun yaşanılan yere, annenin eğitimine, babanın çalışma durumuna ve tutumuna, okulda yaşanılan stres durumuna alkol kullanmalarına ve sigara-alkol dışında herhangi bir bağımlılık yapıcı madde kullanmalarına göre stresle baş etme tarzları alt ölçeklerinde istatistiksel olarak anlamlı bir farklılık olmadığı bulgulanmıştır. 
Çalışmaya alınanların stresle başa çıkmada en fazla etkili olan KGY, ardından etkisiz olan KGÇY kullandıkları ve en az olarak da etkisiz olan BEY'i kullandıkları saptanmıştır.

Araştırma soruları doğrultusunda hemşirelik öğrencilerinin stresle başetme durumlarının etkili olduğu, madde kullanımlarının yüksek olmadığı, sosyodemografik özelliklerine ve özellikle sigara kullanmalarına göre stresle başetme durumları arasında anlamlı bir ilişki olduğu saptanmıştır.

Bu sonuçların doğrultusunda;

Hemşirelik öğrencilerinin yaş arttıkça stresle başetmelerinin etkisiz olduğu sonucuna bağlı olarak hemşirelik öğrencileri için her eğitimöğretim başlangıcında $\mathrm{o}$ yaş dönemine ve 0 ders dönemine özgü stres etkenlerini ve bunların yönetimi konusunda eğitimlerin programlanması,

Bu çalışmada hemşirelik öğrencilerinin stresle başetmelerinin etkili olmasına rağmen ayrıca sigara kullananların da olduğu belirlenmiştir. $\mathrm{Bu}$ nedenle stres yönetiminin daha geniş bir gruba yayılabilmesi için stres yönetiminde etkili olan kendini tanıma, olumlu benlik saygısı geliştirebilme, atılgan olma, çatışma, öfke ve stres yönetimi gibi iletişim becerilerinin 4 yıllık müfredata planlanması ve uygulanması,

Ruhsal olarak probleminin olduğunu belirten öğrencilerin stresle başetmelerinin etkisiz olduğu sonucundan yola çıkarak öğrencilerin ruhsal ve fiziksel sorunlarının araştırııp yardıma intiyacı olan öğrencilerin saptanması ve bunların ilgili yerlere yönlendirilmesi önerilmektedir.

\section{Sınırlılıklar}

Yapılan çalışma sadece uygulama yapılan gruba genellenebilir. Çalışmada kullanılan ölçekler öz bildirime dayalı olduğu için öğrenci kendini rahat ifade edememiş olabilir.

Çıkar İlişkisi: Yazarlar çıkar ilişkisi olmadığını beyan eder.

\section{Kaynaklar}

1. Turhan E, İnandı T, Özer C, Akoğlu, S. Üniversite öğrencilerinde madde kullanımı, şiddet ve bazı psikolojik özellikler. Turk J Public Health 2011;9:33-44.

2. Öztürk O, Uluşahin A. Ruh sağlığı ve bozuklukları. Ankara: Nobel Tıp Kitapevi, 2015.
3. World Drug Report. Available at: https://www.unodc.org/ doc/wdr2016/WORLD_DRUG_REPORT_2016_web. pdf. Erişim tarihi 14 Kasım 2018 (Accessed November 14, 2018).

4. Ögel K. Madde kullanım epidemiyolojisi. J Int Med Sci 2005;1:61-65.

5. Türkiye Uyuşturucu ve Uyuşturucu Bağımlılığı İzleme Merkezi (TUBIM) Ulusal Raporu. Available at: http:// www.narkotik.pol.tr/TUBIM/Documents/TURKIYE\%20 UYUSTURUCU\%20R P RU\%202014.pdf. [2013 verileri]. Erişim tarihi 20 Ekim 2018 (Accessed October 20, 2018).

6. Türkiye İstatistik Kurumu Haber Bülteni (TÜIK). Sayı 24645. Available at: http://www.tuik.gov.tr/HbPrint. do?id=27620. Erişim tarihi 21 Nisan 2017 (Accessed April 21, 2017).

7. Lanier CA, Nicholson T, Duncan D. Drug use and mental well being among a sample of undergraduate and graduate college students. J Drug Educ 2001;31:239248. https://dx.doi.org/10.2190/R7T3-T266-JN9EUX3W

8. Rassol GH, Villar Luis M, Carraro TE, Lopes G. Undergraduate nursing students perceptions of substance use and misuse: a Brazilian position. J Psychiatr Ment Health Nurs 2006;13:85-89. https:// dx.doi.org/10.1111/j.1365-2850.2006.00917.x

9. Güler N, Güler G, Ulusoy H, Bekar M. Lise öğrencileri arasında sigara, alkol kullanımı ve intihar düşüncesi sıklığı. Cumhuriyet Tıp Derg 2009;31:340-345.

10. Türkiye İstatistik Kurumu (TÜIK). Küresel yetişkin tütün araştırması. Available at: http://www.tuik.gov.tr/ PreTablo.do?tb_id=6\&ust_id=1. 2008. Erişim tarihi 1 Ekim 2018. (Accessed October 1, 2018.)

11. Patock-Peckham JA, Morgan-Lopez AA. College drinking behaviors: meditational links between parenting styles, impulse control, and alcohol-related outcomes. Psychol Addict Behav 2006;20:117-125. https://dx.doi. org/10.1037/0893-164X.20.2.117

12. Caldwell LL, Darling N. Leisure context, parental control, and resistance to peer pressure as predictors of adolescent partying and substance use: an ecological perspective. J Leisure Res 1999;31:57-77. https:// dx.doi.org/10.1080/00222216.1999.11949851

13. Türe $M$, Kurt İ, Aktürk Z. Tıp öğrencilerinin sigara ve alkol kullanımının frontal lob kişilik ölçeği ile ilişkisi. Trakya Üniversitesi Tıp Fakültesi Derg 2006;23:19-27.

14. Uz Baş A, Siyez DM. Lise öğrencilerinde, sigara, alkol ve esrar kullanımını yordayıcı bir değişken olarak mükemmeliyetçilik. Yeni Symposium 2010;48:256-263.

15. Friedman AS, Terras A, Zhu W, McCallum J. Depression, negative self-image, and suicidal attempts as effects of substance use and substance dependence. J Addict Dis 2004;23:55-71. https://dx.doi.org/10.1300/ J069v23n04_05 
16. Atak, H. Yetişkinliğe geçiş yıllarında sigara içme davranışlarının psikososyal belirleyicileri ve sigara içmenin yaşam doyumu ve öznel iyi oluşla ilişkisi. Klinik Psikiyatri Derg 2011;14:29-43.

17. Weiss LH, Schwarz JC. The relationship between parenting types and older adolescents' personality, academic achievement, adjustment, and substance use. Child Dev 1996;67:2101-2114. https://dx.doi. org/10.1111/j.1467-8624.1996.tb01846.x

18. Görgün $S$, Tiryaki A, Topbaş M. Üniversite öğrencilerinde madde kullanma ve anne babaya bağlanma biçimleri. Anadolu Psikiyatri Derg 2010;11:305-312.

19. Palfai TP, Ralston TE, Wright LL. Understanding university student drinking in the context of life goal pursuits: the meditational role of enhancement motives. Pers Indiv Differ 2011;50:169-174. https:// dx.doi.org/10.1016/j.paid.2010.09.020

20. Altıok HÖ, Üstün B. Hemşirelik öğrencilerinin stres kaynakları. Kuram ve Uygulamada Eğitim Bilimleri 2013;13:747-766.

21. Pulido-Martos M, Augusto-Landa JM, Lopez-Zafra E. Sources of stress in nursing students: a systematic review of quantitative studies. International Nursing Review 2012;59:15-25. https://dx.doi.org/10.1111/ j.1466-7657.2011.00939.x

22. Baltaş A, Baltaş Z. Stres ve başa çıkma yolları. İstanbul: Remzi Kitabevi, 2004.

23. Folkman S, Lazarus RS. An analysis of coping in a middle-age community sample. J Health Soc Behav 1980;21:219-239. https://dx.doi.org/10.2307/2136617

24. Folkman S, Moskowitz JT. Coping: pitfalls and promise. Annu Rev Psychol 2004;55:745-777. https://dx.doi. org/10.1146/annurev.psych.55.090902.141456

25. Şahin NH, Durak A. Stresle başa çıkma tarzları ölçeği: üniversite öğrencileri için uyarlanması. Türk Psikoloji Derg 1995;10:56-73.

26. Esin MN. Örnekleme. Erdoğan S, Nahcivan N, Esin MN, ed. Hemşirelikte Araştırma süreç, uygulama ve kritik. İstanbul: Nobel tıp kitabevleri, 2014; 167-192.

27. Yavuzer H. Ana-baba ve çocuk. 20. bs. İstanbul: Remzi Kitabevi, 2009.

28. Akkaya S. Ortaöğretim (lise) öğrencilerinde rekabetçi tutum ile ana-baba tutumları arasındaki ilişki düzeyi. Yüksek Lisans Tezi. Sakarya Üniversitesi Sosyal Bilimler Enstitüsü, Sakarya, 2008.

29. Güler Ö, Çınar S. Hemşirelik öğrencilerinin algıladıkları stresörler ve kullandıkları başetme yöntemlerinin belirlenmesi. Maltepe Üniversitesi Hemşirelik Bilim ve Sanatı Derg 2010;Sempozyum Özel Sayısı:253-261.

30. Wolf L, Stidham AW, Ross R. Predictors of stress and coping strategies of US accelerated vs. generic baccalaureate nursing students: an embedded mixed methods study. Nurse Educ Today 2015;35:201-205. https://dx.doi.org/10.1016/j.nedt.2014.07.005
31. Mavili S. Pamukkale Üniversitesi tıp fakültesi öğrencilerinin bağımlılık yapıcı madde kullanım durumları. Uzmanlık Tezi. Pamukkale Üniversitesi Tıp Fakültesi Halk Sağlığı Anabilim Dalı, Denizli, 2017.

32. Çapık C, Cingil D. Hemșirelik öğrencilerinde sigara kullanımı, nikotin bağımlııı düzeyi ve ilișkili etmenler. Kafkas J Med Sci 2013;3:55-61. https://dx.doi. org/10.5505/kjms.2013.91885

33. Çapık C, Özbıçakcı Ş. Dokuz Eylül Üniversitesi Hemşirelik Yüksekokulu öğrencilerinin sigara bağımlııık düzeyleri ve etkileyen etmenler. Uluslararası İnsan Bilimleri Dergisi 2007;4:1-12.

34. Koca B, Oğuzöncül AF. İnönü Üniversitesi Sağlık Yüksekokulu öğrencilerinin sigara, alkol, madde kullanımı, madde kullanımına etki eden etmenler ve aileden aldıkları sosyal desteğin etkisi. Kocaeli Med J 2015;4:4-13.

35. Temel E, Bahar A, Çuhadar D. Öğrenci hemşirelerin stresle baş etme tarzları ve depresyon düzeylerinin belirlenmesi. Fırat Sağlık Hizmetleri Dergisi 2007;2:107-118.

36. Eraslan M. Spor bölümlerinde öğrenim gören üniversite öğrencilerinin kişilik özelliklerinin ve stresle başa çıkma stillerinin çeşitli değişkenlere göre incelenmesi. Mehmet Akif Ersoy Üniversitesi Sosyal Bilimler Enstitüsü Dergisi 2015;7:65-82.

37. Razı GS, Kuzu A, Yıldız AN, Ocakçı AF, Çamkuşu Arifoğlu B. Çalışan gençlerde benlik saygısı, iletişim becerileri ve stresle baş etme. Koruyucu Hekimlik Bülteni 2009;4:17-26.

38. Folkman S. Personal control and stress and coping processes: a theoretical analysis. J Pers Soc Psychol 1984;46:839-852. https://dx.doi.org/10.1037/00223514.46.4.839

39. Holahan C, Moos RH. Personal and contextual determinants of coping strategies. J Pers Soc Psychol 1987;52:946-955. https://dx.doi.org/10.1037/00223514.52.5.946

40. Soderstrom M, Dolbier C, Leiferman J, Steinhardt M. The relationship of hardiness, coping strategies, and perceived stress to symptoms of illness. J Behav Med 2000;23:311-328.

41. Otrar $M$, Ekşi H, Dilmaç $B$, Şirin A. Türkiye'de öğrenim gören Türk ve akraba topluluk öğrencilerinin stres kaynakları, başa çıkma tarzları ile ruh sağlığı arasındaki ilişki üzerine bir araştırma. Kuram ve Uygulamada Eğitim Bilimleri Dergisi 2002;2:477-499.

42. Gibbons GC, Dempster M, Moutray M. Stress, coping and satisfaction in nursing students. J Adv Nurs 2010;67:621-632. https://dx.doi.org/10.1111/j.13652648.2010.05495.x 
43. Türksoy FB. Hemşirelik fakültesi öğrencilerinde benlik saygısı ve stresle baş etme yöntemleri (Ege Üniversitesi Hemşirelik Fakültesi örneği). Yüksek Lisans Tezi. Beykent Üniversitesi Sosyal Bilimler Enstitüsü İşletme Yönetimi Anabilim Dalı Hastane ve Sağlık Kurumları Yönetimi Bilim Dalı, İstanbul, 2014.

44. Kuzgun Y. Ana baba tutumlarının bireyin kendini gerçekleştirme düzeyine etkisi. Ankara: Aile Araştırma Kurumu Yayınları, 1991.

45. Akkuş D, Karaca A, Konuk Şener D, Ankaralı H. Lise öğrencileri arasında sigara ve alkol kullanma sıklığı ve etkileyen faktörler. Anadolu Klin 2017;22:36-45. https:// dx.doi.org/10.21673/anadoluklin.245632

46. Carver CS, Scheier MF, Weintraub JK. Assessing coping strategies: a theoretically based approach. J Pers Soc Psychol 1989;56:267-283. https://dx.doi. org/10.1037/0022-3514.56.2.267

47. Vingerhoets AJJM, Van Heck GL. Gender, coping, and psychosomatic symptoms. Psychol Med 1990;20:125135. https://dx.doi.org/10.1017/S0033291700013301

48. Gates PJ, Albertella L. The cannabis information helpline: assessing interest in the medicinal use of cannabis in Australia. Subst Use Misuse 2017;52:16341638. https://dx.doi.org/10.1080/10826084.2017.1298 616

49. Williams SC, Davey-Rothwell MA, Tobin KE, Latkin C. People who inject drugs and have mood disorders-a brief assessment of health risk behaviors. Subst Use Misuse 2017;52:1181-1190. https://dx.doi.org/10.1080 /10826084.2017.1302954

50. Yalçın M, Eşsizoğlu A, Akkoç H, Yaşan A, Gürgen F. Dicle üniversitesi öğrencilerinde madde kullanımını belirleyen risk faktörleri. Klinik Psikiyatri 2009;12:125133.

51. Zachrison L, Ruchkin V, Stickley A, Koposov R. Inhalant use and mental health problems in Russian juvenile delinquents. Subst Use Misuse 2017;52:1616-1623. https://dx.doi.org/10.1080/10826084.2017.1293106

52. Ano GG, Vasconcelles EB. Religious coping and psychological adjustment to stress: a meta-analysis. J Clin Psychol 2005;61:461-480. https://dx.doi. org/10.1002/jclp.20049

53. Tarhan N. Mutluluk psikolojisi. İstanbul: Timaş Yayınları, 2013.

54. Robertson $\mathrm{AA}, \mathrm{Xu} X$, Stripling $\mathrm{A}$. Adverse events and substance use among female adolescent offenders: effects of coping and family support. Subst Use Misuse 2010;45:451-472. https://dx.doi. org/10.3109/10826080903452512

55. Terzi CK. Ergenlerde saldırganlığın madde bağımlıı̆̆ı ve diğer değişkenlerle ilişkisi. Yüksek Lisans Tezi. Gazi Üniversitesi Eğitim Bilimleri Enstitüsü, Ankara, 2009.
Teşekkür: Çalışmaya katılanlara teşekkür ederiz. Bu çalışma, II. Uluslararası Gençlik Araştırmaları Kongresi'nde sözel bildiri olarak sunulmuştur, 25-29 Ekim 2017 Muğla. 